\title{
13. Exile as an Awakening of Consciousness: Jiří Weil, Ladislav Fuks, Arnošt Lustig
}

Having discussed three writers of the Holocaust who are famous in the West, let us now turn to some less prominent authors who wrote in Czech. Weiss wrote in German, Wiesel became well known after the French edition of Night, and Levi wrote in Italian, but was translated into English by Raymond Rosenthal and widely read.

Jiří Weil, Ladislav Fuks, and Arnošt Lustig, on the other hand, all wrote in Czech and only Lustig was widely published in English because of his late exile to the US after 1968 and because some of his works were turned into films. These writers present a very different take on the lives of Jews during WWII. The Czech sensibility is unique. It contains aspects of absurdity and Surrealism, twisted humor and lyricism, individualism, eroticism, and profundity. It is aesthetic rather than strictly rational.

Jiř́i Weil, an outstanding Czech Jewish author (b. 1900 in Praskolesy, d. 1959 in Prague) wrote among other things a masterful little novel titled A Life with Star (1949), which in a very direct and unexpected way takes on the issue of how to create meaning in the absolutely absurd world into which the hero is thrown. Weil was an avant-garde artist and member of Devětsil (an influential avantgarde association of artists founded in 1920 in Prague), an awardwinning novelist, a literary translator, a journalist, and a curator. He was one of the first to write about the Soviet purges in a novel, the very first writer to set a novel in a Gulag, and among the first writers (together with Arnošt Lustig and Ladislav Fuks) to consider the fate of the Czech Jews in WWII.

A pupil of the prominent critic F. X. Šalda, Weil studied philosophy and comparative literature at Charles University, 
Prague, and was one of the first translators of contemporary Russian literature into Czech (Pasternak, Mayakovsky, Tsvetaeva). He worked in Russia as a journalist in the 1930s, but after the assassination of Kirov, he was thrown out of the Communist Party and exiled to Central Asia. ${ }^{57}$ He returned to Prague in 1935 and published a novel about the Soviet purges in 1937. During the Nazi occupation, he escaped deportation to the Terezín (Theresienstadt) ghetto by staging his own death and going into hiding until the end of the war.

His best-known work Life with a Star was published just after the 1948 Communist February Putsch in Czechoslovakia and thus received a poor reception, as it was labeled by the new authorities as decadent, existentialist, highly subjective, the "product of a cowardly culture" and banned. He was only readmitted into the Writers' Union after the death of Klement Gottwald. ${ }^{58}$

He was introduced to American readers by Philip Roth and today he is considered a major Czech writer. Critics agree that his is one of the most outstanding works about the Holocaust and the fate of individual Jews.

Weil never mentions the words "Jew," "German," or "Nazi" in the whole book, yet, and perhaps because of it, he produces a sense of authenticity, as well as urgency and timelessness. He further switches between impersonal and objective narration and subjective narration, which gives the narrator agency with regard to reality. ${ }^{59}$

57 Sergei Mironovich Kirov, First Secretary of the central committee of the Azerbaijani Communist Party and a personal friend of Joseph Stalin. He rose through the ranks of the Communist Party of the Soviet Union to become head of the party in Leningrad and a member of the Politburo. He was assassinated in 1934. His death was later used as a pretext to escalate political repression in the Soviet Union and Great Purge that followed. Weil's persecution was part of the aftermath of his death.

58 Klement Gottwald was the first Communist president of Czechoslovakia. During his rule the most deadly purges were carried out. He died only several days after Stalin in 1953.

59 See also, Eva Štědroňová, “Dialektika umělecké metody a reality v díle Jiř́ho Weila," Česká literatura 38, no. 2 (1990): 130. 
The novel describes the existence of a solitary Jew, Josef Roubíček living in Prague during the German occupation. He lives without an income, in hunger and cold, ostracized and degraded, and tries to get through life without getting murdered. He is bombarded by daily prohibitions on anything and everything and by the daily fear of being called for deportation, which he knows is a journey to death. He is an orphan who was brought up by abusive relatives, which has resulted in an anxious and cowardly attitude to life. In his mind, he is constantly having conversations with Rủžena, his married lover, who is no longer around, as she has emigrated with her husband.

Roubiček, however, is too afraid to follow suit, as many of his compatriots also were. It is scary and difficult to move to a strange country and he cannot overcome his fear. He is simply forced into an inner exile of the most gruesome and absurd kind. One of his acquaintances commits suicide in order to improve his daughter's life: he believes her life will be easier with him gone, as she is a child of mixed marriage. His fellow Jews, who are wealthier than him, are easier targets for the Nazis, as robbing the Jews is their first and foremost goal. Roubíček's friends and neighbors check their future possessions before their Jewish acquaintances are deported, as they are virtually already dead.

The best part of Roubíček's life takes place at a cemetery, where he cultivates some vegetables in order to survive. His best friend is a stray cat, who he secretly adopts, as Jews are not allowed to have pets and are even ordered to kill them. He has to pretend the cat is actually just a stray, even though he becomes his bed and table companion. The cat is eventually shot by the Nazis for sport and eaten by his neighbors, while Josef is forced to pretend to have no feelings about the matter.

He eventually realizes, though, how reduced and thwarted his life has become purely due to his own fear of death. This creates a major personal breakthrough for him after a long fear-based existence. He decides against joining a transport when called and goes into hiding. We do not find out anything about his further fate, but it is implied that he has found a path toward a meaningful life through his epiphany. He understands now that should he die, he 
will be actually free. The cemetery appears as a peaceful place; the dead are safe from the Nazis.

People around Josef die not only in an inhuman way, but also in an absurd way, exhausted and numbed by waiting for death and desperately trying to defend themselves against the horrendous conditions they are subjected to. They die inside by scheming how to save this or that tiny part of their existence or possessions. Their martyrdom becomes an absurd martyrdom and death an absurd death. But Josef also understands that the Jews absurdly helping the enemy to dig their own graves is due to their holding onto hope. Hope is thus a major source of degradation. Josef's victory over himself is a victory over hope. The internal exile he has condemned himself to, because of his fear of external exile, is transformed into a concept of exile as abandoning hope, in a positive sense, into understanding life as transcending death.

Ladislav Fuks (b. 1923 in Prague, d. 1994 in Prague), on the other hand, who wrote several important novels about the periods of the Holocaust and Communist regime-for example, Mr. Theodor Mundstock (1963), Variation on the Dark String (1966), The Burner of the Corpses (1967, made into a famous film by Juraj Herz in 1968), and Of Mice and Mooshaber (1970)-turns the same topics into Surrealist dreamlike nightmares. His obsession with the topic of Jewish persecution during the Nazi occupation of Czechoslovakia, to which his best novels refer, is interesting also because he himself was not a Jew. He was, however, a homosexual and thus subject to a very similar kind of ostracism as Jews. He makes his heroes escape into an unreal, dreamlike world, where their circumstances and their reactions to these circumstances are multiplied and exaggerated. The reader is confronted with a nightmarish experience, which forces them to receive the book's message on a subconscious level. The reader might also be more willing to face up to the contents of the novels because they seem "unreal."

Fuks explicitly uses a method of literary mystification. ${ }^{60} \mathrm{He}$ intentionally thwarts his narrative, filling it with words, themes,

60 See Ladislava Lederbuchová, "Ladislav Fuks a literární mystifikace," Česká literatura 34, no. 3 (1986): 232-244. 
motives, and stories that appear to have one meaning, but later on turn out to mean something completely different. His early works deal with the Holocaust in very personal and ingenious ways. The Burner of the Corpses has been turned into a well-known Czech New Wave film. His later works are more abstract, and are harder for readers to decipher.

His books are not allegories, as they might seem, but complicated structures of meaning that interact on many planes. The protagonist of Of Mice and Mooshaber, for example, appears as an enigmatic and abused old woman throughout the novel. She is suspected of using rat poison on children, but at the end she turns into a powerful aristocrat who was in disguise the whole time. The reader is thus forced to suddenly reevaluate the whole semantic structure of the book and the reality they have been exposed to.

Unfortunately, Ladislav Fuks was among those that after the Soviet invasion in 1968 was willing to reconcile with the regime rather than stand up to it. His strongest works, then, are those written in the 1960s about the German occupation.

Other significant Jewish authors coming from Czechoslovakia dealt with exile and extreme conditions in a much lighter way. Arnošt Lustig (b. 1926 in Prague, d. 2011 in Prague) is probably the most renowned of the Czech Jewish authors. His many novels and stories focus primarily on the fate of Jews in the Holocaust. He views the Jews as the embodiment of the general human problem of the twentieth century, namely the conflict between destructive and impersonal political power and the individual.

The theme of the awakening of individual human consciousness is the predominant subject of Lustig's works. His protagonists are often young women. His works achieved success even during the Communist era, as they offered a fresh perspective by removing themselves from the prescribed ideological fiction of the time. His major achievement is his presentation of inhuman conditions as an everyday matter. In this sense, his protagonists are ordinary.

This denial of hero status was another revolutionary act during the Communist period. Despite Lustig's popularity and the relative approbation he received in the 1960s, he decided to emigrate to America after the Soviet occupation in 1968, where he achieved 
success as a professor of literature at the American University in Washington D.C., as well as a writer and filmmaker.

His road to success in America, however, was not easy. His first books, including the novel The Prayer for Katarina Horowitzova (1964), which was made into a successful film later on, first received a fairly negative reception. ${ }^{61}$ It might be Lustig's ingenious idea of focusing on a group of rich American Jews, portrayed in a rather negative light that made the novel unappealing to critics. Yet it was precisely this that made it possible for the novel to get published and appreciated in Communist Czechoslovakia in the 1960s. It also gives the book a wider perspective. While showing the clear amorality and ruthlessness of the Germans, the novel at the same time does not idealize the Nazis' victims or paint a black-and-white picture. The reader follows the story with a curious eye, rather than with mere disgust for the Germans. It is the one novel by Lustig that has an unambiguous heroine in the person of the young Polish dancer Katarina. She is presented as pure, wholesome, and strong, capable of resistance and a conscious stance that puts everybody else to shame.

On the whole, however, Lustig's work is characterized by its avoidance of heroic topics and its refusal to celebrate the Czech resistance. He chose mostly very young people for his protagonists and, in his later works, especially young girls, who sell their bodies to improve their lives in the concentration camps.

In conclusion, I would like to briefly mention a few other major Czech writers who addressed the idea of Jews as outcasts.

Viktor Fischl (Avigdor Dagan) (b. 1912 in Hradec Králové, d. in Israeli exile in 2006) fled to Israel at the beginning of WWII to flee from the Nazi terror. He belongs among the most important exiled writers who were, at the time, interested in what was happening to European Jews. He worked for many years as an Israeli diplomat. His most famous novel Dvorní šašci (Court jester, 1990) describes the fate of a Jew who has survived a concentration camp due to his physical handicap and his role as an entertainer.

61 Abraham Rothberg, review of A Prayer for Katerina Horovitzova, by Arnost Lustig, Southwest Review 59, no. 1 (Winter 1974): 87-89. 
Jan Otčenášek (b. 1924 in Prague, d. 1979 in Prague) is a Czech non-Jewish writer famous for his novel Romeo, Juliet, and Darkness (1958) about the young love between a Jewish girl in hiding and a Czech student during the German occupation. The novel was made into a successful film. The setting and outcome are very similar to Anne Frank's - the innocence of youth violated by an ugly and pitiless world.

Norbert Frýd (b. 1913 in České Budějovice, d. 1976 in Prague) is the author of Box of Lives (1956), a novel based on his own experiences in German concentration camps.

Ladislav Grosman (b. 1921 in Humenné, Slovakia, d. 1981 in Tel Aviv), is a Slovak Jewish author who later wrote in Czech and became world famous because of his screenplay for the film Shop on Main Street (1965), which was directed by Jánoš Kádár and Elmar Klos. He emigrated to Israel after the Soviet invasion of 1968.

The topic of the persecution of the Jews during the German occupation described by Czech-Jewish authors was readily accepted during the Communist regime, even if it did not fit the strict demands of Socialist Realism, as it also served to capture something of the suffering of the Czechs and Slovaks under the Nazis. The awakening of consciousness, which sometimes takes the form of a subtle shift in perception, sometimes a psychological breakthrough under extreme duress and isolation (see Weil, Lustig, and Fuks), is the thread that unifies these writings 